\title{
Macroecology of marine mammal species in the Mexican Pacific Ocean: diversity and distribution
}

\author{
Hiram Rosales-Nanduca ${ }^{1}$, Tim Gerrodette ${ }^{2}$, Jorge Urbán-R. ${ }^{3}$, \\ Gustavo Cárdenas-Hinojosa ${ }^{3}$, Luis Medrano-González ${ }^{1, *}$
}

\author{
${ }^{1}$ Facultad de Ciencias, Universidad Nacional Autónoma de México, Circuito exterior, Ciudad Universitaria, México, \\ DF 04510, Mexico \\ ${ }^{2}$ Southwest Fisheries Science Center, National Marine Fisheries Service, National Oceanic and Atmospheric Administration, \\ 3333 North Torrey Pines Court, La Jolla, California 92037, USA \\ ${ }^{3}$ Departamento de Biología Marina, Universidad Autónoma de Baja California Sur, Km 5.5 Carretera al Sur, La Paz, \\ BCS 23080, Mexico
}

\begin{abstract}
The Mexican Pacific Ocean, defined as east of $122^{\circ} \mathrm{W}$ and from 12 to $34^{\circ} \mathrm{N}$, encompasses an oceanographic transition zone with dynamic population and community processes. In order to gain insight into possible marine mammal ecological responses to the current rapid environmental changes, we compiled and analyzed data from 11145 marine mammal sightings made between 1981 and 2008 by the National Oceanic and Atmospheric Administration, the Universidad Autónoma de Baja California Sur, and the Universidad Nacional Autónoma de México. In $2 \times 2^{\circ}$ cells, we computed alpha and beta diversities in terms of species richness, commonness as the occurrence of species among years, tropicality as the proportion of tropical species, and degree of threat according to the IUCN Red List. Current marine mammal distributions seem to derive from a postglacial northwards expansion of tropical pelagic species and a retention of upwelling-rich tropical and subtropical habitats nearshore by antitropical species. Analysis of commonness indicates that species distributions and thus biogeographic boundaries are dynamic, since marine mammals transit large distances, especially around southern Baja California. Analysis of beta diversity showed a considerable degree of spatial heterogeneity, but without well-defined regions. The species at risk are concentrated in the northern Gulf of California, but also occur off Pacific Baja California, Jalisco, and Guerrero coasts. The Gulf of California could be considered a refuge of global value for these animals.
\end{abstract}

KEY WORDS: Marine macroecology $\cdot$ Marine mammal $\cdot$ Mexican Pacific $\cdot$ Geographic distribution Species diversity $\cdot$ Species risk $\cdot$ Species commonness

Resale or republication not permitted without written consent of the publisher

\section{INTRODUCTION}

The eastern tropical Pacific is a region of global biological and economic importance, part of which comes from a diverse and abundant marine mammal fauna (Ballance et al. 2006, Ferguson et al. 2006, Fiedler \& Talley 2006, Schipper et al. 2008). The Pacific Ocean west of Mexico is an oceanographic transition region, seasonally variable between 18 and $23^{\circ} \mathrm{N}$ (Wyrtki 1967), between the cooler waters of the California Current and the warmer waters of the North Equator- ial Current. In this transition zone, many species reach the limits of their distributions, and thus biogeographic boundaries occur (Briggs 1973, Spalding et al. 2007). Up to 44 marine mammal species may be found in the Mexican Pacific region, which is operationally defined here in the intervals 12 to $34^{\circ} \mathrm{N}$ and from the American Pacific coast to $122^{\circ} \mathrm{W}$ (e.g. Wade \& Gerrodette 1993, Reeves et al. 2002, Kaschner et al. 2011). The relatively high diversity of marine mammals in the Mexican Pacific results primarily from the co-occurrence of tropical and antitropical species (Torres et al. 1995, 
Ballance et al. 2006, Medrano González et al. 2008). Some of these species have been widely studied, while others are known only from a few records. Geographical distribution and its temporal variation is known in detail for a few species such as those of the genera Stenella and Delphinus (Perrin et al. 1985, Fiedler \& Reilly 1994, Reilly \& Fiedler 1994, Ballance et al. 2006).

In the present study, we analyzed spatial variation in marine mammal diversity in the Mexican Pacific from sighting data collected by the National Oceanic and Atmospheric Administration (NOAA), the Universidad Autónoma de Baja California Sur (UABCS), and the Universidad Nacional Autónoma de México (UNAM) during the years 1981 to 2008, in order to (1) infer historical and current processes controlling marine mammal distributions at the biogeographic boundaries within the Mexican Pacific; (2) develop an analytical framework to examine marine mammal ecological responses to current rapid environmental changes (e.g. Anderson 2001, Harwood 2001, Moore 2008,
O'Shea \& Odell 2008, MacLeod 2009) and risk for marine diversity loss (e.g. Reid 1998, Myers et al. 2000, Pauly et al. 2002, Malakoff 2004, Worm et al. 2005); and (3) identify priority conservation areas for marine mammals of the Mexican Pacific based on different criteria such as diversity, occurrence of rare species, and occurrence of threatened species. We have entitled our work using the term macroecology sensu (Brown 1999, p. 4) as 'a way of investigating the empirical patterns and mechanistic processes by which the particulate components of complex ecological systems generate emergent structures and dynamics.'

\section{MATERIALS AND METHODS}

Data collection. We defined the Mexican Pacific region operationally as 12 to $34^{\circ} \mathrm{N}$ latitude and from the coast to $122^{\circ} \mathrm{W}$ longitude (Fig. 1, Table 1). For this area, we compiled information on 11145 marine mam-
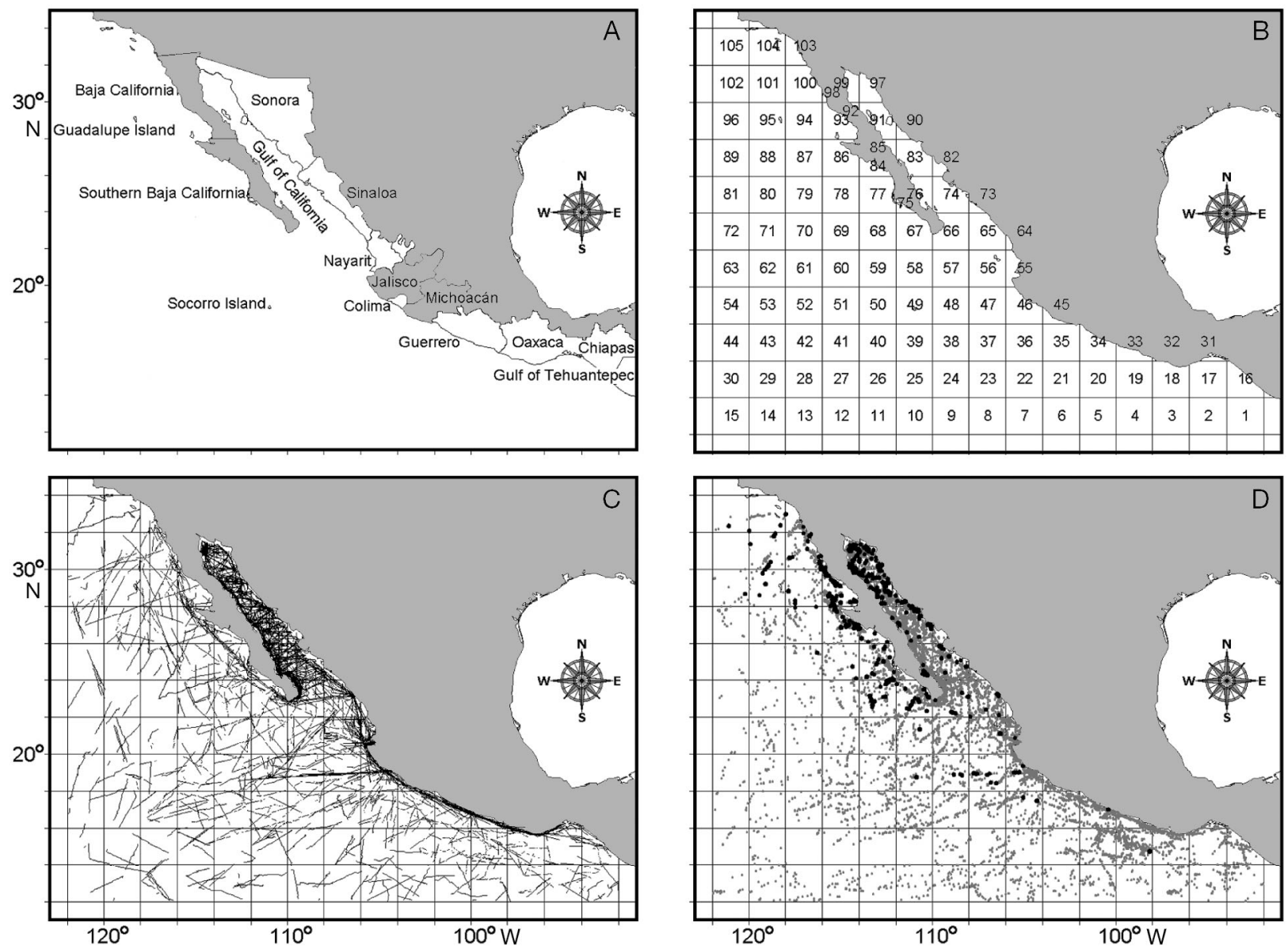

Fig. 1. (A) Study area, indicating the Mexican states on the Pacific coast and other areas mentioned in the text. (B) Partition and identity of cells in the studied region. (C) Observation effort for marine mammals during 1981 to 2008 by the National Oceanic and Atmospheric Administration (NOAA), Universidad Autónoma de Baja California Sur (UABCS), and the Universidad Nacional Autónoma de México (UNAM) in the Mexican Pacific corresponding to Table 1. (D) Corresponding marine mammal sightings. Cetaceans are indicated with gray dots and pinnipeds with black circles 
mal sightings, of which 8598 were identified to 37 species (Table 2). These data were obtained in cruises by the Southwest Fisheries Science Center, NOAA, during 1986 to 2006, UABCS during 2003 to 2007, and

Table 1. Summary of observation effort for marine mammals by the National Oceanic and Atmospheric Administration (NOAA), Universidad Autónoma de Baja California Sur (UABCS), and Universidad Nacional Autónoma de México (UNAM) in the Mexican Pacific region

\begin{tabular}{|lcrcccc|}
\hline & Years & $\begin{array}{c}\text { No. } \\
\text { years }\end{array}$ & $\begin{array}{c}\text { On-effort } \\
\text { transect } \\
\text { length }(\mathrm{km})\end{array}$ & $\begin{array}{c}2^{\circ} \text { cell } \\
\text { coverage } \\
(\%)\end{array}$ & $\begin{array}{c}\text { No. } \\
\text { sightings }\end{array}$ & $\begin{array}{c}\text { No. } \\
\text { species }\end{array}$ \\
\hline NOAA & $1986-2006$ & 14 & 109368 & 99 & 7517 & 34 \\
UABCS & $2003-2007$ & 5 & 34578 & 20 & 1749 & 24 \\
UNAM & $1981-1985$ & 11 & 61107 & 49 & 1879 & 29 \\
& $2003-2008$ & & & & & \\
Total & $\mathbf{1 9 8 1 - 2 0 0 8}$ & $\mathbf{2 4}$ & $\mathbf{2 0 5 0 5 3}$ & $\mathbf{1 0 0}$ & $\mathbf{1 1 1 4 5}$ & $\mathbf{3 7}$ \\
\hline
\end{tabular}

Table 2. Marine mammals registered in this study

\begin{tabular}{|lll|}
\hline Scientific name & Common name & Abbreviation \\
\hline Balaenoptera acutorostrata & Common minke whale & Bacu \\
Balaenoptera borealis & Sei whale & Bbor \\
Balaenoptera edeni & Bryde's whale & Bede \\
Balaenoptera musculus & Blue whale & Bmus \\
Balaenoptera physalus & Fin whale & Bphy \\
Megaptera novaeangliae & Humpback whale & Mnov \\
Eschrichtius robustus & Gray whale & Erob \\
Physeter macrocephalus & Sperm whale & Pmac \\
Kogia breviceps & Pygmy sperm whale & Kbre \\
Kogia sima & Dwarf sperm whale & Ksim \\
Berardius bairdii & Baird's beaked whale & Bbai \\
Indopacetus pacificus & Longman's beaked whale & Ipac \\
Mesoplodon densirostris & Blainville's beaked whale & Mden \\
Mesoplodon peruvianus & Pygmy beaked whale & Mper \\
Mesoplodon carlhubbsi & Hubb's beaked whale & Mcar \\
Ziphius cavirostris & Cuvier's beaked whale & Zcav \\
Feresa attenuata & Pygmy killer whale & Fatt \\
Globicephala macrorhynchus & Short-finned pilot whale & Gmac \\
Orcinus orca & Killer whale & Oorc \\
Pseudorca crassidens & False killer whale & Pcra \\
Peponocephala electra & Melon-headed whale & Pele \\
Steno bredanensis & Rough-toothed dolphin & Sbre \\
Lagenorhynchus obliquidens & Pacific white-sided dolphin & Lobl \\
Grampus griseus & Risso's dolphin & Ggri \\
Tursiops truncatus & Common bottlenose dolphin & Ttru \\
Stenella attenuata & Pantropical spotted dolphin & Satt \\
Stenella coeruleoalba & Striped dolphin & Scoe \\
Stenella longirostris & Spinner dolphin & Slon \\
Delphinus delphis & Short-beaked common dolphin & Ddel \\
Delphinus capensis & Long-beaked common dolphin & Dcap \\
Lagenodelphis hosei & Fraser's dolphin & Lhos \\
Phocoena sinus & Vaquita & Psin \\
Arctocephalus galapagoensis & Galápagos fur seal & Agal \\
Arctocephalus townsendi & Guadalupe fur seal & Atow \\
Zalophus californianus & California sea lion & Zcal \\
Mirounga angustirostris & Northern elephant seal & Mang \\
Phoca vitulina & Harbor seal & Pvit \\
\hline
\end{tabular}

UNAM during 1981 to 1986 and 2003 to 2008 for a total observation effort of $205053 \mathrm{~km}$. See Kinzey et al. (2000) and Medrano González et al. (2008) for details on effort and data collection procedures. The study area was divided into cells of $2 \times 2^{\circ}$, in each of which we computed alpha and beta diversity, commonness, tropicality, and degree of threat. These attributes were chosen because they allowed information from the 3 datasets with different methodologies to be combined (Table 1). Such complementarity was allowed because the heterogeneities of search effort among cells as well as the differences in the observation methodologies used by the 3 institutions can be dealt with from the lists of sightings, with list size as a measure.

Species distribution, coverage, and commonness. The study area occupied 101 squares of $2 \times 2^{\circ}$, of which 4 had areas in both the Pacific Ocean and the Gulf of California, to yield a total of 105 cells (Fig. 1). Coverage of the study area by a species was defined as the fraction of cells in which the species was recorded. Commonness of each species in each cell was defined as the fraction of the years in which the species was recorded of the years the cell was visited (Magurran \& Henderson 2003). Seasonal variation was not examined, although it is partly covered in our discussion of the dynamics of spatial distributions.

Species diversity and uniqueness. Species richness by cell, as a measure of species diversity, was the sum of all recorded species. In order to standardize the differences of effort among cells, species richness, $R_{\max }$, was also estimated by the exponential and hyperbolic models described by Soberón \& Llorente (1993). The exponential model was:

$$
R_{j}=R_{\max }[1-\exp (-b j)]
$$

and the hyperbolic model was:

$R_{j}=R_{\max } \frac{j}{k+j}$ (Michaelis-Menten)

where $R_{j}$ is the cumulative number of species with $j$ records, $b$ is a parameter accounting for the decreasing proba- 
bility to record a new species as the number of records accumulates, and $k$ is a parameter accounting for the rate at which richness increases as records accumulate. We estimated these parameters using the method of least squares. The exponential model is adequate to estimate richness in well-sampled areas, while the hyperbolic model works better for areas with less intensive sampling. The hyperbolic saturation model fitted better in 61 cells, while the exponential saturation was best suited for 11 cells. For 33 cells with insufficient data, estimation of richness was calculated as the average of the estimated richness of adjacent cells. Beta diversity was defined following Whittaker (1972) as differences in species richness between adjacent cells and is a measure of how unique a cell within a region is. We analyzed beta diversity on 2 hierarchical levels of variation. We defined alpha diversity $(R \alpha)$ as the species richness in a cell, and gamma diversity $(R \gamma)$ as the diversity in the cell and all cells adjacent to it. The local uniqueness of the cell and thus how different is it from its neighborhood, is beta diversity $(R \beta \geq 1)$, for which total diversity in the cell and its neighborhood is:

$$
R \gamma=R \alpha R \beta
$$

The richness found in all cells $(R \varepsilon)$ was then quantified as a second level of beta-type variation that we named delta diversity $(R \delta \geq 1)$ and which is given by the differences among cells and neighborhoods within the whole studied region, so that:

$$
R \varepsilon=R \delta R \gamma=R \delta R \beta R \alpha
$$

Therefore, uniqueness of individual cells with reference to the global diversity in all cells is $R \beta R \delta$. $R \delta$ is much less sensitive to failures in richness estimation due to the scarcity of data in some cells. To minimize diversity differences due to heterogeneous effort and data amounts between cells, $R \alpha, R \gamma$, and $R \varepsilon$ were estimated by the hyperbolic accumulation model of Soberón \& Llorente (1993) with parameters estimated by least squares. For each cell then, $R \alpha$ was counted and estimated with 2 accumulation models, and the beta-type diversities $R \beta$ and $R \delta$ were estimated with the hyperbolic model with 2 fitting approaches.

Biogeographic origin and risk level. Biogeographical affinity of cells was analyzed in terms of tropicality, defined as the fraction of tropical species. Tropical species were defined as having a distribution mainly between the Tropics of Capricorn and Cancer (Medrano González 2006). We analyzed species threat level in cells according to the International Union for Conservation of Nature (IUCN) Red List (www.iucnredlist. org/mammals) in the following ordinal scale: 0: least concern (LC) and data deficient (DD), 1: near threatened (NT), 2: vulnerable (VU), 3: endangered (EN), and 4: critically endangered (CR). Risk measures at cells were the median and maximum risk level of all species in the cell, as well as the frequencies of the classes in the intervals 1 to 4 (NT, VU, EN, CR), 2 to 4 (VU, EN, CR), 3 to 4 (EN, CR), and 4 (CR). The frequency of risk classes in the interval 1 to 4 was weighted by estimated richness, species rarity (defined as 1 - commonness), and $R \beta$ to identify areas with priority for conservation of marine mammals, taking into account biological attributes of these animals and not only their risk condition.

The programs ANHOSPP (to determine species commonness at cells), CURVAC (to set up accumulation curve data), ACUMUMM (to estimate hyperbolicmodel parameters directly to the Michaelis-Menten equation), REGINVMM (to estimate hyperbolic-model parameters to the Lineweaver-Burk equation by linear regression of the accumulation-curve data-inverses), and NUMORD (to determine species risk-measures at cells) were developed by L. Medrano-González (unpubl.) These programs are available as executable and as TurboPascal source code upon request.

\section{RESULTS}

From a total of 11145 marine mammal sightings between 1981 and 2008 in the Mexican Pacific region, 8598 were identified to species level. In total, 37 species were recorded, which included 1 record of Longman's beaked whale Indopacetus pacificus. Five species were pinnipeds (Pinnipedia) and 32 were cetaceans (Cetacea), among which 7 were baleen whales (Mysticeti), 15 were dolphins (Delphinidae), 3 were sperm whales (Physeteroidea), 1 was a porpoise (Phocoenidae), and 6 were beaked whales (Ziphiidae). Dolphins were the most widely distributed group, as they were found in $100 \%$ of the cells surveyed. Dolphins were followed by baleen whales (82\%), beaked whales $(61 \%)$, sperm whales $(57 \%)$, pinnipeds $(37 \%)$, and porpoises $(2.9 \%)$.

Based on the difference between adjacent species in the commonness rank of Fig. 2, we distinguished 3 primary sets that we called common, not-so-common, and rare species. The most common species were in general those occupying the largest ranges, such as the 3 Stenella species ( $S$. attenuata, S. longirostris, and $S$. coeruleoalba), the bottlenose dolphin Tursiops truncatus and the short-beaked common dolphin Delphinus delphis. Common species also included the fin whale Balaenoptera physalus and the long-beaked dolphin D. capensis, resident in the Gulf of California. Rare species in general had the smallest ranges. Rare species included some extralimital species, such as Hubb's beaked whale Mesoplodon carlhubbsi and the Galapagos fur seal Arctocephalus galapagoensis, some common spe- 


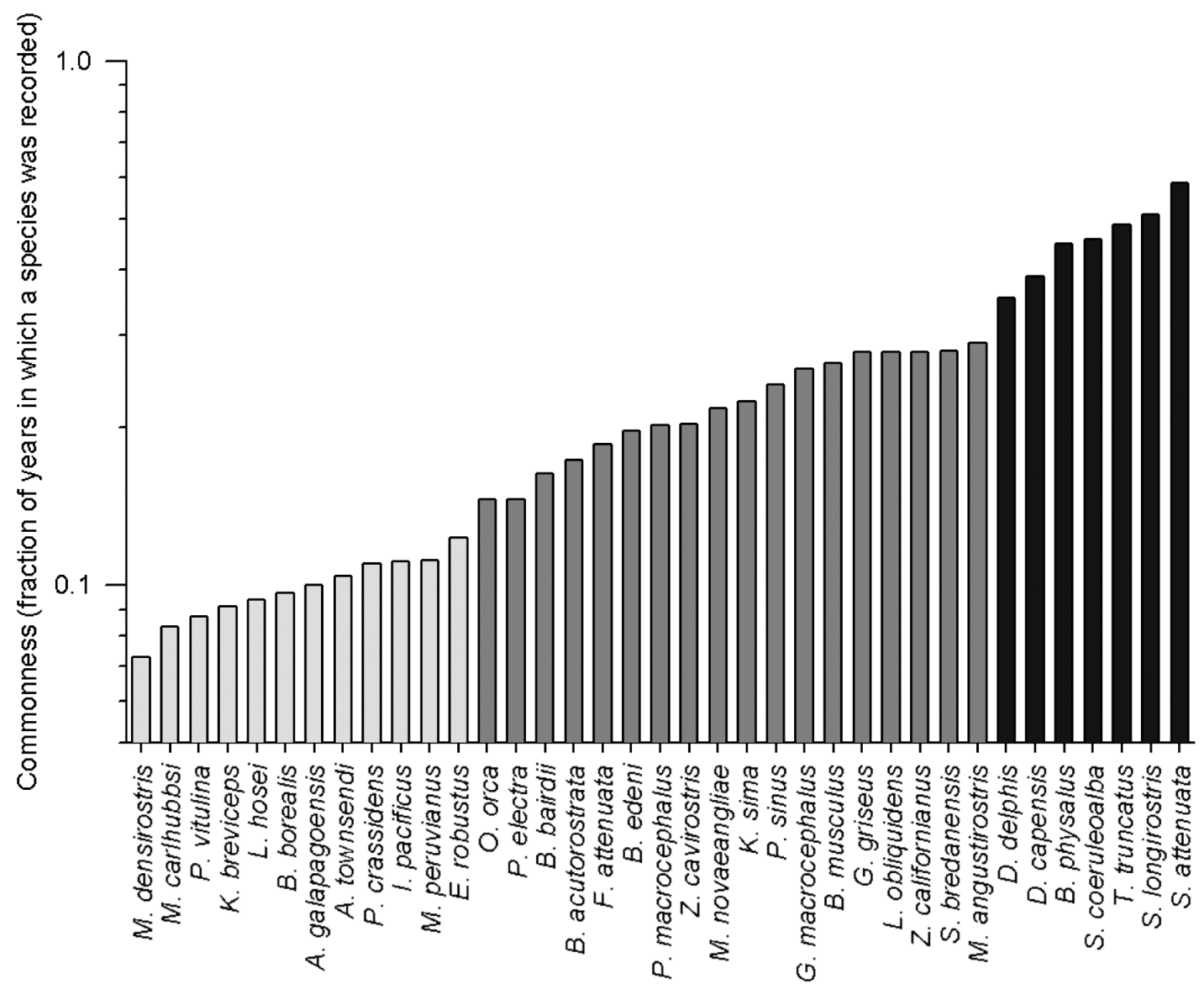

Fig. 2. Array of the mean fraction of years in which species were recorded in cells (commonness) for marine mammal species in the Mexican Pacific Ocean. Three main groups of commonness are indicated by bar colors (common: black; not-so-common: gray; rare: light gray)

cies outside their core ranges, such as the Guadalupe fur seal A. townsendi and the gray whale Eschrichtius robustus, and some truly rare and/or scarce species, such as Fraser's dolphin Lagenodelphis hosei and the pygmy beaked whale Mesoplodon peruvianus.

We found a general correspondence between commonness and coverage among commonness classes; a $\log$-log regression of the 37 species yielded the allometric relationship: Commonness $\propto$ Coverage $^{0.31}\left(\mathrm{r}^{2}=\right.$ 0.50). However, there was high variation in coverage within commonness classes, and for all 3, we observed 2 blocks of coverage (low and high) which defined a total of 6 groups (Fig. 3). Common species all appeared above the regression line, while not-so-common and rare species were mostly located under it. Species commonness was also bimodal, with Stenella spp., Tursiops truncatus and Balaenoptera physalus as the most common species (ca. 0.6). Commonness was in general lower in the Pacific area off Baja California as well as higher and more irregular westwards and southwards. Small patches of commonness occurred around Socorro Island and Bahía Banderas (Fig. 4).
Composition of diversity in $2 \times 2^{\circ}$ cells showed a higher species richness in waters close to shore off the southern Baja California Peninsula. Two different accumulation-curve models indicated that this pattern was consistent. Richness was high around the Baja California Peninsula with high contrasts between adjacent cells at the northern Gulf of California, in the Gulf of Tehuantepec, and in the southwest pelagic region. There were some patches of high diversity in the waters between the Baja Peninsula and Guadalupe Island, around Socorro Island, and off the Guerrero coast. Cell 66, at the southern end of Baja California, showed the highest observed richness with 26 species out of a total of 37 , while cell 74, north of cell 66, had the highest estimated richness with 31 species out of a total of 42 (Fig. 5).

$R \beta$ is expected to indicate biogeographic boundaries, but our results showed irregular, partial, and diffuse patterns. We recognized at least the following boundaries: (1) the Midriff Islands in the Gulf of California, (2) the west coast of northern Baja California extending southwards to the pelagic region off southern Baja 


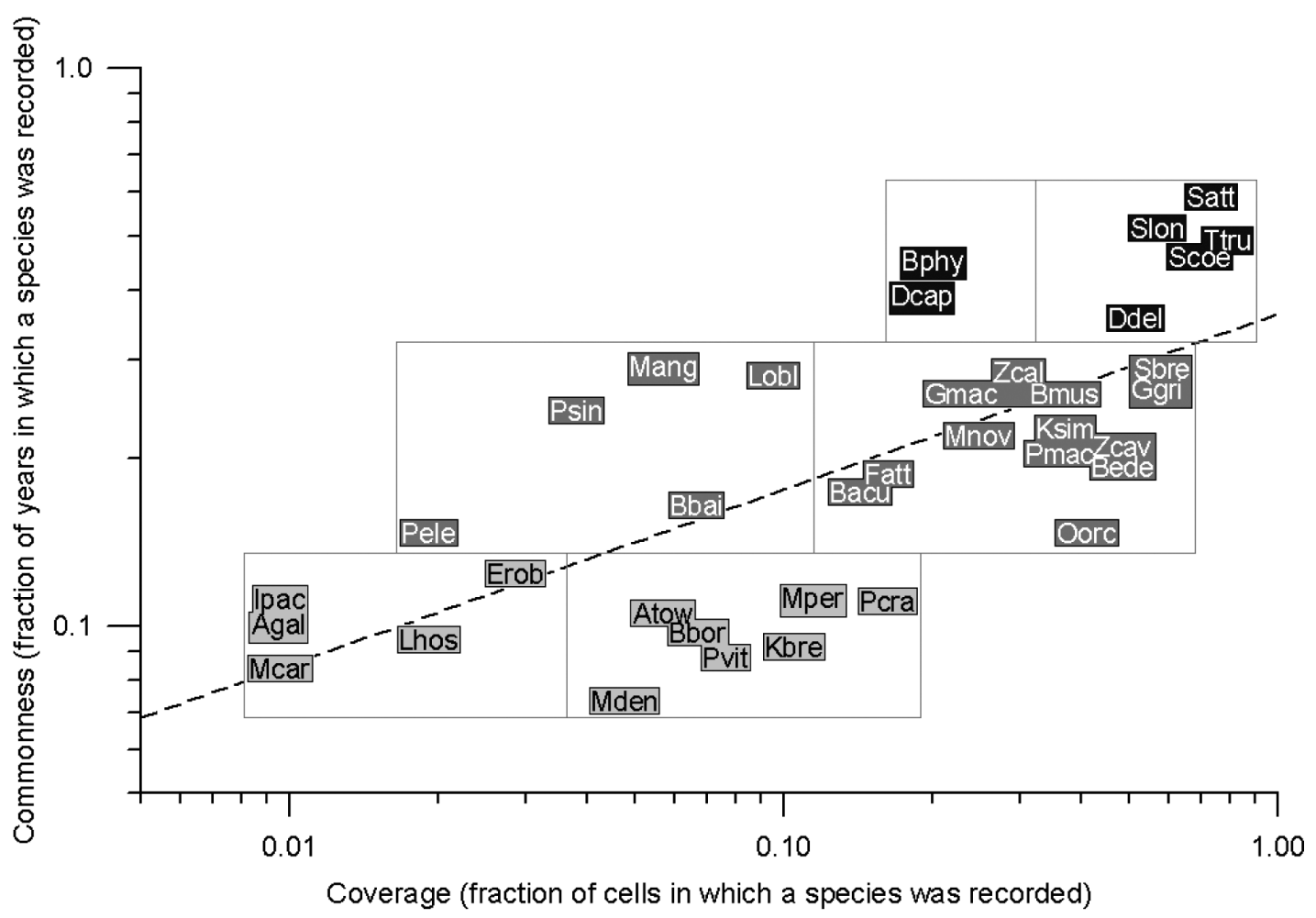

Fig. 3. Relationship between coverage and commonness of marine mammals in the Mexican Pacific Ocean. Commonness class is indicated by colors as in Fig. 2. Six groups of coverage and commonness are indicated. Dashed lines indicate linear regression with slope $=0.31$ and $\mathrm{r}^{2}=0.50$. Species abbreviations are given in Table 2

California; and (3) the Tehuantepec Gulf and adjacent southern margin. The Baja California boundary may extend to the mouth of the Gulf of California, as insinuated by the higher $R \beta$ value of cell 57 . Such limits suggest the following faunistic regions based on marine mammal diversity: (1) the Upper Gulf of California, (2) the Gulf of California south of the Midriff Islands region down to the mouth and including the Pacific coast off southern Baja California north up to San Benito Islands, (3) the northern west coast of Baja California, (4) the pelagic region north of latitude $22^{\circ} \mathrm{N}$, (5) the pelagic region south of latitude $20 \mathrm{~N}$ and (6) the coastal area between the mouth of the Gulf of California and the Gulf of Tehuantepec.

Marine mammal community heterogeneity on the broader scale of $R \delta$ showed a simpler and smoother pattern than $R \beta$. $R \delta$ had the Baja California-centered pattern described for species richness, but in this case, $R \delta$ was low around the edge of the Baja Peninsula and in the southern and central Gulf of California. $R \delta$ smoothly increased away from this region and then steeply increased towards the edges of the study area and at the northern Gulf of California (Fig. 6). The product of delta and beta diversities $(R \beta R \delta$, uniqueness of cells with reference to total diversity) was intermediate between $R \beta$ and $R \delta$ patterns and remarkably similar to the tropicality map. Both maps were the inverse of the species richness map (Figs. $5 \& 7$ ). Modeled as a function of $R \beta R \delta$, tropicality scaled with $R \beta R \delta$ as: Tropicality $=0.96[1-\exp (-1.15 R \beta R \delta)]$, with $\mathrm{r}^{2}=0.46$. Tropicality scaled with $R \alpha$ as: Tropicality $=$ $-8.05 R \alpha+1.03$, with $r^{2}=0.48$. Both regressions were statistically significant by the $F$-test $(p<0.01)$.

Of the total 37 species recorded, 24 were tropical (63\%). Tropical species occurred in all cells while nontropical species occurred in 75 cells ( $71 \%$ coverage). The minimum fraction of tropical species present in all cells was $72 \%$. In general, tropicality of species composition increased away from the Baja California Peninsula at the boundary of the California Current and the Gulf of California. It was noticeable that marine mammals from the northern Gulf of California had a high degree of tropicality in contrast to the rest of the Gulf (Fig. 7).

All measures of species risk in cells showed the same general spatial pattern. Most of the Mexican Pacific showed low risk values for marine mammals, but high values were concentrated around the Baja California Peninsula. Species risk values were higher in the upper half of the Gulf of California, especially north of the Midriff Islands. The risk scale based on the record with the maximum risk value was of relevance as it shows the occurrence of threatened species without a mask- 


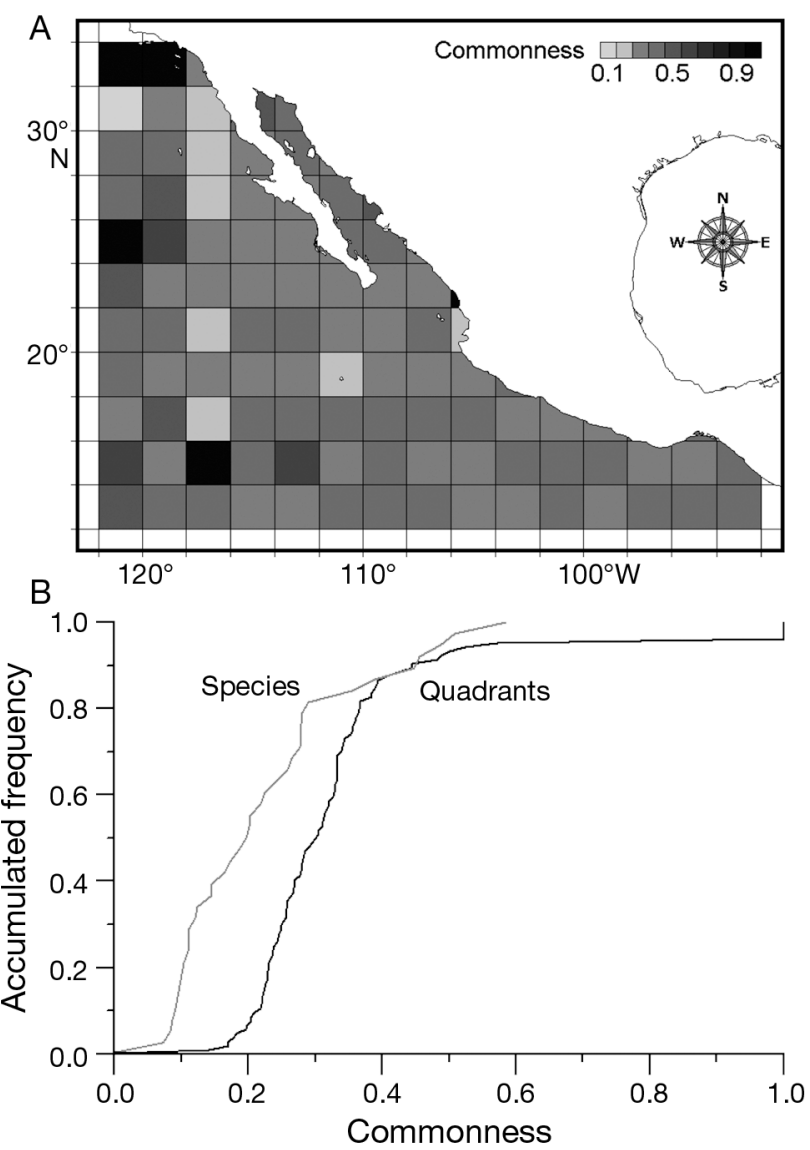

Fig. 4. (A) Geographic distribution of mean commonness (fraction of years in which a species was recorded) of marine mammals in the Mexican Pacific Ocean. (B) Accumulated frequency-distribution of mean commonness by species (gray line) and cells (black line)

ing effect of the occurrence of non-threatened species. This scale showed highest levels of risk in coastal and pelagic waters in the range 20 to $34^{\circ} \mathrm{N}$, in coastal waters southward down to Guerrero and Oaxaca coasts, and a pelagic patch around $14^{\circ} \mathrm{N}$ (Fig. 8A,B). Maps in which species risk was weighted by estimated richness, beta diversity, and rarity all had a similar pattern, indicating that the Midriff Islands area, the upper Gulf of California, and the waters around the Pacific coast of Baja California Peninsula are areas of marine mammal conservation priority (Fig. 8G-I).

\section{DISCUSSION}

From the fact that estimation of marine mammal richness in 72 out of 105 cells worked well with the hyperbolic and exponential species-accumulation models of Soberón \& Llorente (1993), we concluded that marine mammal diversity across the Mexican Pacific is in general well estimated by our data. The 33
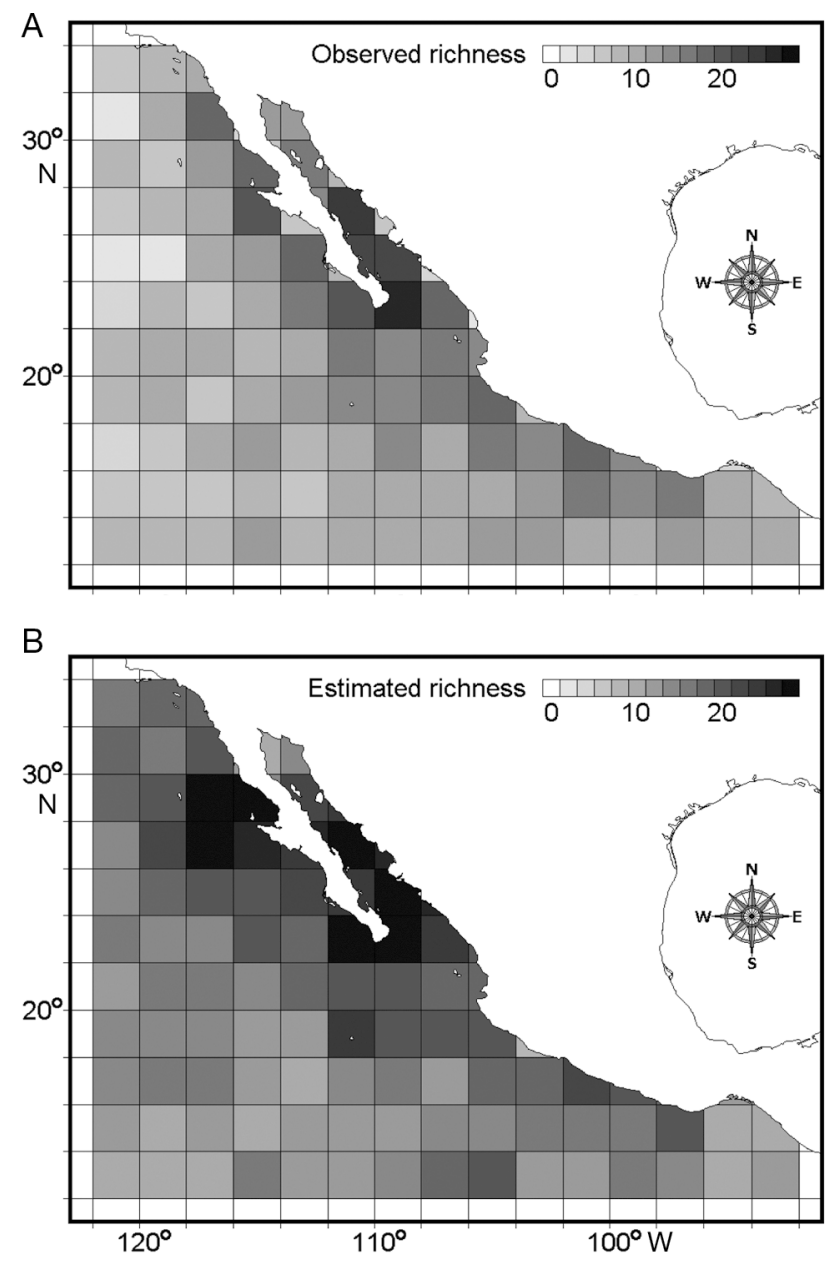

Fig. 5. Species richness of marine mammals in the Mexican Pacific Ocean. (A) Observed richness. (B) Richness estimated from the accumulation models of Soberón \& Llorente (1993)

poorly sampled cells for which richness was not estimated are located mostly in the margins of the study area. In total, 37 species were observed. From a totalrichness accumulation curve, we estimated the occurrence of 42 species, but know of the possible existence of up to 44 species, of which we failed to detect 7 species from the North Pacific biogeographic region: the locally extirpated Enhydra lutris, and the recently discovered Mesoplodon perrini, as well as the marginal Phocoenoides dalli, Lissodelphis borealis, M. stejnegeri, M. ginkgodens, and Eubalaena japonica. Our data failed to record those species because of the lack of effort in the Pacific coast of Baja California during the winter and the springtime. We consider this to be the greatest gap in our study.

There was a general pattern of high values of $R \alpha$ around the southern edge of Baja California, and $R \alpha$ decreased with distance from the peninsula. Lower $R \alpha$ values occurred in the northern Gulf of California and higher values occurred along the coast between Guer- 

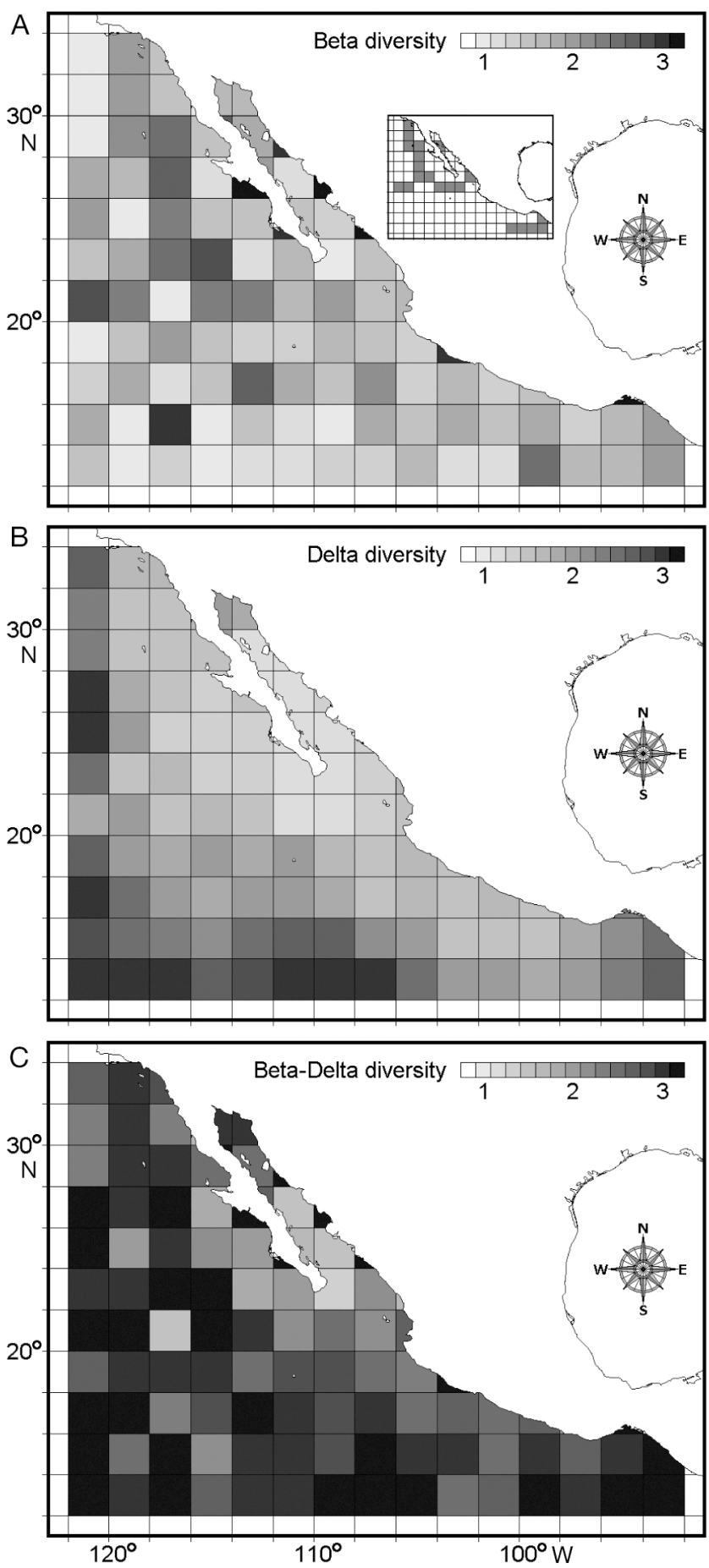

Fig. 6. Geographic distribution of (A) beta and (B) delta diversities and $(\mathrm{C})$ their combination among marine mammals in the Mexican Pacific Ocean. The small map enclosed in panel

(A) depicts the interpreted boundaries from this figure

rero and the western Gulf of Tehuantepec. The inverse pattern was seen for $R \delta$ and tropicality. Excluding cells with small sample sizes, richness spots also occurred around Guadalupe and Socorro Islands. The Jalisco

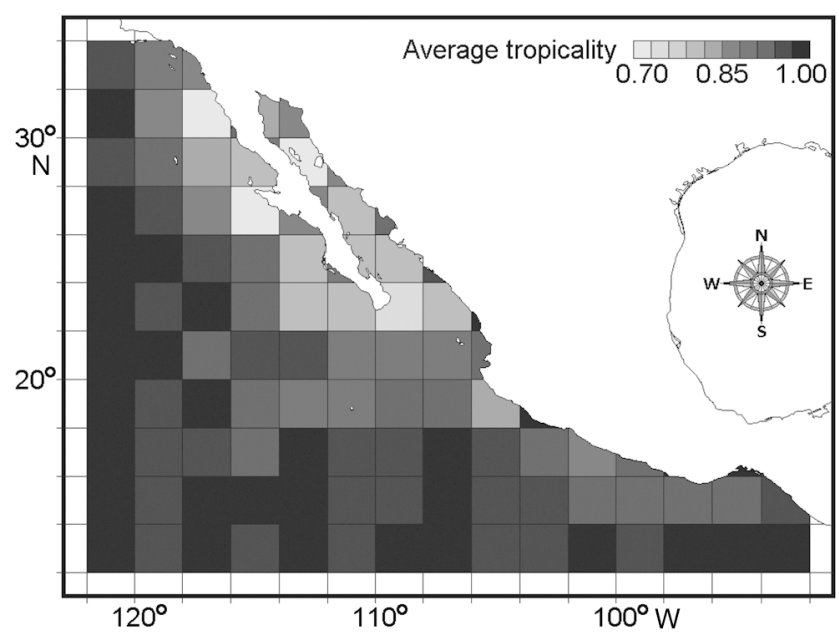

Fig. 7. Geographic distribution of marine mammals in the Mexican Pacific Ocean according to their primary biogeographic origin (tropical or antitropical). Tropicality: fraction of tropical species

coast was an area of low tropicality but high maximum-risk values.

Patterns of richness, uniqueness at different scales, and tropicality are all in agreement with the hypothesis that current marine mammal distributions in the Mexican Pacific result from a northward postglacial expansion of tropical pelagic species and a retention of upwelling-rich tropical and subtropical habitats nearshore by antitropical species (Medrano González 2006, Medrano González et al. 2008). Pelagic species are relatively homogeneous, but coastal populations can be fragmented, as with the spotted dolphin Stenella attenuata (Escorza-Trevino et al. 2002). Because of their great vagility and physiological regulation capacities, distributions of marine mammals change more in the form of expansions and contractions in dynamic adaptation to variable suitable habitats, rather than to shifts following specific environmental conditions (Fiedler \& Reilly 1994, Reilly \& Fiedler 1994, Ballance et al. 2006, Medrano González 2006). Therefore, processes which affect population structure, such as dispersion and growth, occur at large geographic scales, such as the interhemispheric gene flow among humpback whales Megaptera novaeangliae of the eastern Pacific (Baker et al. 1993, Medrano-González et al. 2001). Studies on genetic variation (Bérubé et al. 2002, Escorza-Trevino et al. 2002, Schramm Urrutia 2002, Natoli et al. 2006) as well as on distribution and morphological variation (Davies 1963, Perrin 1984, Perrin et al. 1985, Fiedler \& Reilly 1994, Reilly \& Fiedler 1994, Ballance et al. 2006, Fiedler \& Talley 2006) of marine mammals in the eastern Tropical Pacific show that different species share some aspects of their population structure and history, as their geographic distributions were shaped by 

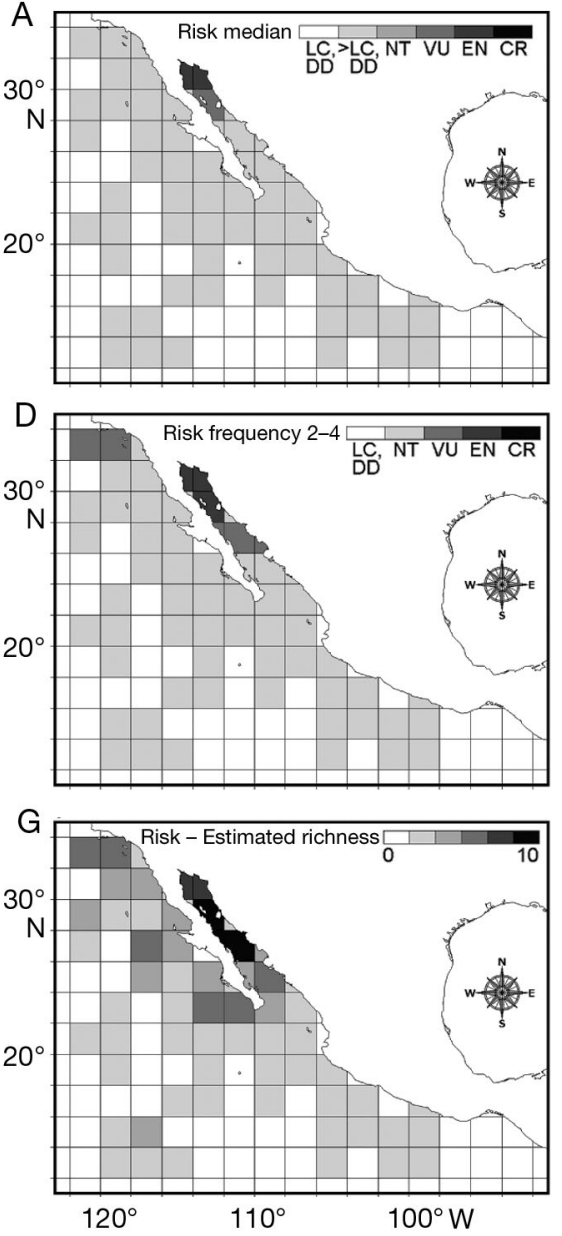
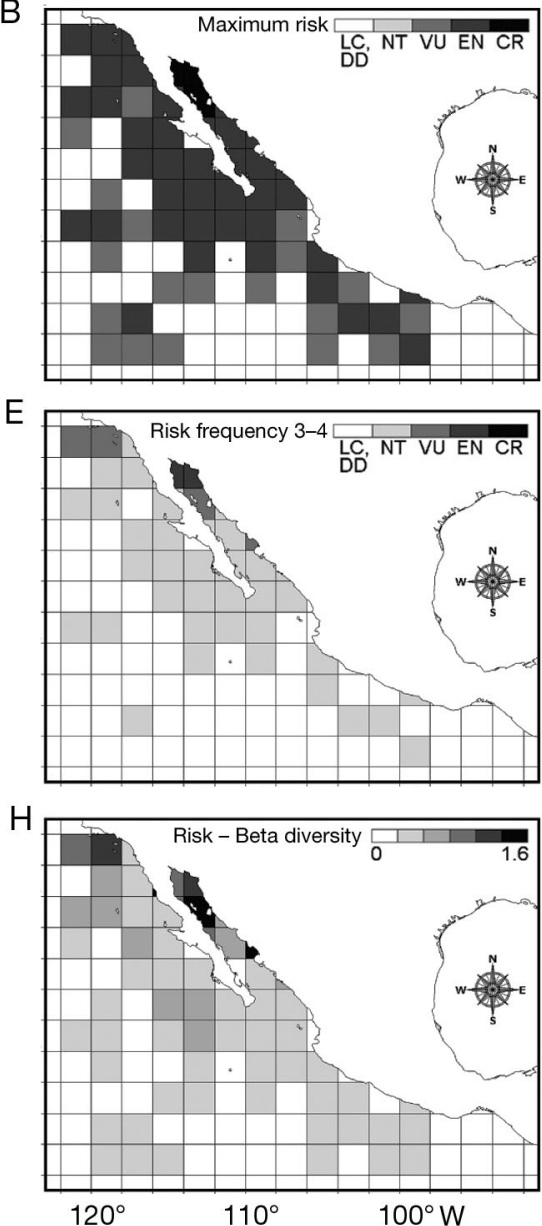
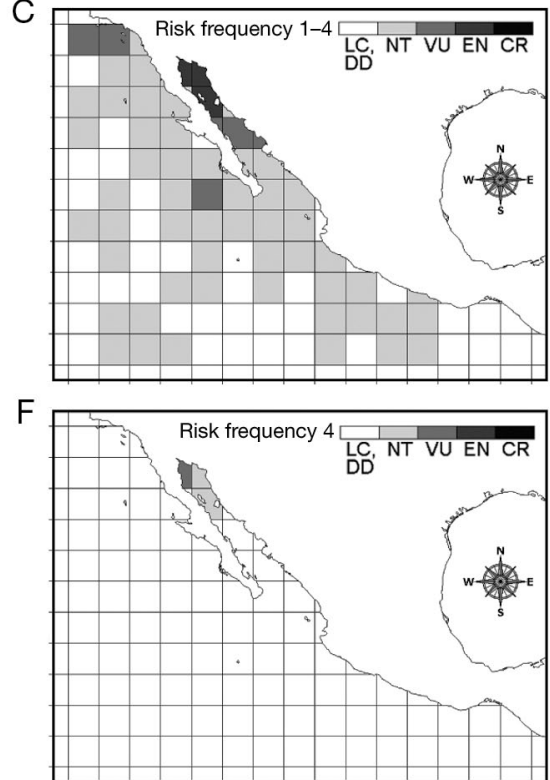

I

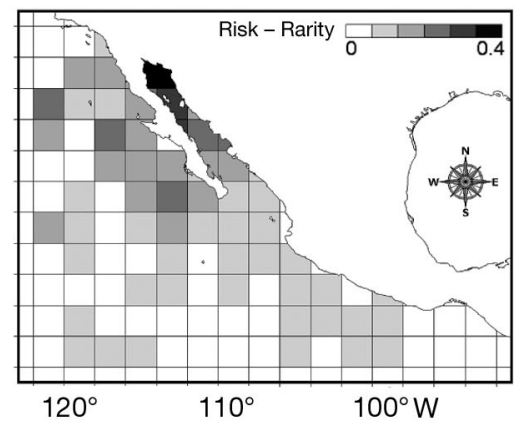

Fig. 8. Distribution of marine mammals in the Mexican Pacific Ocean according to risk scale used by the IUCN. (A) Risk median, (B) maximum risk, (C-F) frequencies of risk classes 1 to 4,2 to 4,3 to 4 and 4, respectively, (G) frequency of risk classes 1 to 4 weighted by estimated species richness, $(\mathrm{H})$ frequency of risk classes 1 to 4 weighted by beta diversity, (I) frequency of risk classes 1 to 4 weighted by species rarity. See 'Materials and methods: Biogeographic origin and risk level' for a detailed description of risk classes, abbreviations and calculations

glacial-interglacial alternations. An important aspect of distribution change of marine mammals of the eastern North Pacific is the establishment of local nearshore populations such as the distributions of the neritic spotted dolphin Stenella attenuata graffmani on the continental coast south of $23^{\circ} \mathrm{N}$ and the longbeaked common dolphin Delphinus capensis in the Gulf of California and off the Pacific Baja California coasts (Perrin 1984, Perrin et al. 1985, Rosel et al. 1994, Escorza-Trevino et al. 2002, Natoli et al. 2006).

Analysis of $R \beta$ shows poorly defined patterns (Fig. 6A), probably due to the many types of temporal (yearly and seasonal, regular, e.g. migratory, and irregular) variations in species distributions not considered in this study. However, we recognized 6 faunistic regions which have a general resemblance to those described by Lara-Lara et al. (2008) and Wilkinson et al. (2009) on the basis of neritic-benthonic and pelagic environments, as well as on large geostructures such as continental slopes, abyssal plains, mountain ranges, and oceanic islands. The Regions 1, 2 and 6 which we identified are also coincident with the stock boundaries of Delphinus delphis by Perrin et al. (1985). $R \beta$ decreased towards the southwest pelagic region, and we concluded that marine mammal communities are more homogeneous southward in the pelagic realm.

The map $R \beta R \beta$ (Fig. 6C) is remarkably similar to the tropicality map (Fig. 7), and they both are almost the exact inverse of the species richness map (Fig. 5). We concluded that tropical marine mammals are nearly uniformly distributed within the studied region, especially in the extensive pelagic environments, while antitropical species occurence is restricted to coastal environments around the Baja California Peninsula, and is seemingly associated with upwelling (Ballance et al. 2006).

Commonness by species (Fig. 4B) was on average lower compared to commonness by cells, and we inter- 
pret this as being indicative of mesoscale distribution change among years. Variation in distribution, indicated by smaller commonness values, was higher around southern Baja California, suggesting that marine mammals occur in this region mostly in transit among the tropical Pacific, the North Pacific, and the Gulf of California regions. The steep topography allows coastal and pelagic species to occur close together. The particular oceanography and ecology of the Gulf of California, especially its high productivity, has favored endemism and local adaptations, as exemplified by the vaquita, the fin whale, the sperm whale, the long-beaked common dolphin, and the California sea lion (Ferguson et al. 2006, Schramm-Urrutia 2002, Urbán-Ramírez et al. 2005). Nevertheless, distributions of feeding and calving areas for marine mammals in the Gulf of California are different, indicating rapid transit within the Gulf of California as well as between the Gulf and the adjacent Pacific Ocean (Arellano Peralta 2010). Transit, especially around the southern Baja California coast, is therefore relevant for the life of marine mammals and is also a main factor accounting for changes in species distributions and biogeographic boundaries.

Our risk picture for marine mammals is different from the picture of marine anthropogenic impacts by Halpern et al. (2008). Our map of maximum risk, in particular, looks like the inverse of the map presented by Halpern et al. (2008), in which the Pacific region off Baja California shows lower impacts, while the coastal and adjacent pelagic regions between Nayarit and Guerrero as well as a few regions within the Gulf of California show higher impacts. Therefore, we raise concern about the fact that marine mammal fauna around the Baja California Peninsula down to $18^{\circ} \mathrm{N}$ has an intrinsic high vulnerability and thus that human developments in this area may have particularly negative impacts on these animals as compared to other regions. Our results agree with those of Halpern et al. (2008), i.e. that the northern Gulf of California is an important habitat for some threatened species, such as the fin whale, the sperm whale, and particularly the endemic vaquita. We note that 14 marine mammal species of the Mexican Pacific (38\% of the 37 species recorded in the present study) are ranked 'Data Deficient' by the IUCN, and thus our measures of risk may be underestimated. The frequency of risk classes 1 to 4 seems to be an adequate metric of spatial patterns of conservation priorities, in terms of balancing the occurrence of high- and low-risk species, of properly contrasting differences among cells, and of maximizing spatial coverage. The maximum risk map (Fig. 8B) may also be useful in defining minimum conservation sites in the short term.

Spatial patterns of diversity, commonness, and tropicality of marine mammals in the Mexican Pa- cific region indicate historical processes, such as alternating glacial and interglacial periods, which have shaped the current distributions and assemblies of these animals. Such patterns also show that marine mammal distributions and assemblies are quite dynamic. The characteristic migration of these animals between feeding and calving areas may also be a result of past environmental variation. The plasticity of marine mammal distributions has important consequences for conservation priorities. One important result is the high occurrence of threatened marine mammals within the Gulf of California in contrast to the adjacent Pacific Ocean. The Gulf of California may be a refuge of global value for these animals, reflecting the global oceanographic and biological uniqueness of this sea (Arellano Peralta 2010).

Acknowledgements. We are greatly indebted to all those in NOAA, UABCS, and UNAM who have, at sea or in laboratories, contributed to building the analyzed dataset. We acknowledge in particular the work of A. Aguayo, V. A. Arellano, H. Arita, L. F. Bourillón, M. A. Fernández, L. T. Findley, A. Gómez, E. Martínez, E. M. Peters, L. Rojas, M. A. Salinas, S. E. Smith, M. J. Vázquez, O. Vidal, many students at UNAM and UABCS, the scientific and operative crews of RV 'El Puma,' as well as the support by Posgrado en Ciencias Biológicas UNAM, H. Armada de México, Instituto Nacional de Ecología, Secretaría del Medio Ambiente y Recursos Naturales, Consejo Nacional de Ciencia y Tecnología (by funding project $38605-\mathrm{V}$ and the scholarship to H.R.N.), and the OBIS Seamap. For the NOAA information, we thank the numerous observers who collected data, the officers and crews of the NOAA vessels, and many people at the Southwest Fisheries Science Center. NOAA data were collected under research permits issued by the Mexican government, and we thank L. Rojas for allowing access to them. We finally thank L. Ballance and 2 anonymous reviewers for their detailed and helpful comments.

\section{LITERATURE CITED}

Anderson PK (2001) Marine mammals in the next one hundred years: twilight for a Pleistocene megafauna? J Mammal 82:623-629

Arellano Peralta VA (2010) Mamíferos marinos en el Golfo de California: macroecología, impacto humano y su perspectiva hacia la conservación. MS dissertation, Universidad Nacional Autónoma de México, Mexico City

Baker CS, Perry A, Bannister JL, Weinrich MT and others (1993) Abundant mitochondrial DNA variation and worldwide population structure in humpback whales. Proc Natl Acad Sci USA 90:8239-8243

Ballance LT, Pitman RL, Fiedler PC (2006) Oceanographic influences on seabirds and cetaceans of the eastern tropical Pacific: a review. Prog Oceanogr 69:360-390

Bérubé M, Urbán J, Dizon AE, Brownell RL, Palsbøll PJ (2002) Genetic identification of a small and highly isolated population of fin whales (Balaenoptera physalus) in the Sea of Cortez, México. Conserv Genet 3:183-190

Briggs JC (1973) Marine zoogeography. McGraw-Hill, New York, NY

Brown JH (1999) Macroecology: progress and prospect. Oikos $87: 3-14$ 
Davies JL (1963) The antitropical factor in cetacean speciation. Evolution 17:107-116

Escorza-Trevino S, Lang A, Dizon AE (2002) Genetic differentiation and intraspecific structure of eastern tropical Pacific spotted dolphins, Stenella attenuata, revealed by mitochondrial and microsatellite DNA analyses. Report LJ-02-38. NOAA-SWFSC, La Jolla, CA

Ferguson MC, Barlow J, Fiedler P, Reilly SB, Gerrodette T (2006) Spatial models of delphinid (family Delphinidae) encounter rate and group size in the eastern tropical Pacific Ocean. Ecol Model 193:645-662

Fiedler PC, Reilly SB (1994) Interannual variability of dolphin habitats in the eastern tropical Pacific. II: Effects on abundance estimated from tuna vessel sightings, 1975-1990. Fish Bull 92:451-463

Fiedler PC, Talley LD (2006) Hydrography of the eastern tropical Pacific: a review. Prog Oceanogr 69:143-180

Halpern BS, Walbridge S, Selkoe KA, Kappel CV and others (2008) A global map of human impact on marine ecosystems. Science 319:948-952

Harwood J (2001) Marine mammals and their environment in the twenty-first century. J Mammal 82:630-640

Kaschner K, Tittensor DP, Ready J, Gerrodette T, Worm B (2011) Current and future patterns of global marine mammal biodiversity. PLoS ONE 6(5):e19653, doi:10.1371/ journal.pone.0019653

Kinzey D, Olson P, Gerrodette T (2000) Marine mammal data collection procedures on research ship line-transect surveys by the Southwest Fisheries Science Center. Administrative Report LJ-00-08. Southwest Fisheries Science Center, La Jolla, CA

Lara-Lara JR, Arenas FV, Bazán GC, Díaz CV and others (2008) Los ecosistemas marinos. In: Capital natural de México, Vol 1: Conocimiento actual de la biodiversidad. CONABIO, México City, p 135-139

MacLeod CD (2009) Global climate change, range changes and potential implications for the conservation of marine cetaceans: a review and synthesis. Endang Species Res 7:125-136

Magurran AE, Henderson PA (2003) Explaining the excess of rare species in natural species abundance distributions. Nature 422:714-716

Malakoff D (2004) New tools reveal treasures at ocean hot spots. Science 304:1104-1105

Medrano González L (2006) Hacia una dinámica de la mastofauna marina mexicana: análisis de composición funcional y de algunas estructuras genéticas poblacionales. In: Vázquez-Domínguez E, Hafner DJ (eds) Genética y mamíferos mexicanos: presente y futuro. N M Mus Nat Hist Sci Bull 32:9-19

Medrano-González L, Baker CS, Robles-Saavedra MR, Murrell J and others (2001) Trans-oceanic population genetic structure of humpback whales in the North and South Pacific. Mem Queensl Mus 47:465-479

Medrano González L, Rosales-Nanduca H, Vázquez-Cuevas MJ, Urbán-Ramírez J and others (2008) Diversidad, composiciones comunitarias y estructuras poblacionales de la mastofauna marina en el Pacífico mexicano y aguas adyacentes. In: Lorenzo C, Espinoza E, Ortega J (eds) Avances en el estudio de los mamíferos de México II. Asociación Mexicana de Mastozoología AC. San Cristóbal de las Casas, p 469-492

Moore SE (2008) Marine mammals as ecosystem sentinels. J Mammal 89:534-540

Myers N, Mittermeier RA, Mittermeier CG, da Fonseca GAB,

Editorial responsibility: John Piatt,

Anchorage, Alaska, USA
Kent J (2000) Biodiversity hotspots for conservation priorities. Nature 403:853-858

Natoli A, Cañadas A, Peddemors VM, Aguilar A, Vaquero C, Fernández-Piqueras $\mathrm{P}$, Hoelzel AR (2006) Phylogeography and alpha taxonomy of the common dolphin (Delphinus sp.). J Evol Biol 19:943-954

> O'Shea TJ, Odell DK (2008) Large-scale marine ecosystem change and the conservation of marine mammals. J Mammal 89:529-533

Pauly D, Christensen V, Guénette S, Pitcher TJ and others (2002) Towards sustainability in world fisheries. Nature 418:689-695

Perrin WF (1984) Patterns of geographical variation in small cetaceans. Acta Zool Fenn 172:137-140

Perrin WF, Scott MD, Walker GJ, Cass VL (1985) Review of geographical stocks of tropical dolphins (Stenella spp. and Delphinus delphis) in the eastern Pacific. NOAA Rep NMFS-28. La Jolla, CA

Reeves RR, Stewart BS, Clapham PJ, Powell JA, Folkens PA (2002) Guide to marine mammals of the world. National Audubon Society. Alfred A. Knopf, New York, NY

> Reid W (1998) Biodiversity hotspots. Trends Ecol Evol 13: $275-280$

Reilly SB, Fiedler PC (1994) Interannual variability of dolphin habitats in the eastern tropical Pacific. I: Research vessel surveys, 1986-1990. Fish Bull 92:434-450

Rosel PE, Dizon AE, Heyning JE (1994) Genetic analysis of morphotypes of common dolphins (genus Delphinus). Mar Biol 119:159-167

Schipper J, Chanson JS, Chiozza F, Cox NA and others (2008) The status of the world's land and marine mammals: diversity, threat, and knowledge. Science 322:225-230

Schramm-Urrutia Y (2002) Estructura genética y filogeografía del lobo marino de California (Zalophus californianus californianus) en aguas adyacentes a la Península de Baja California, México. PhD thesis. Facultad de Ciencias Marinas, Universidad Autónoma de Baja California, Ensenada

Soberón JM, Llorente J (1993) The use of species accumulation functions for the prediction of species richness. Conserv Biol 7:480-488

Spalding MD, Fox HE, Allen GR, Davidson N and others (2007) Marine ecoregions of the world. A bioregionalization of coastal and shelf areas. Bioscience 57:573-583

Torres GA, Esquivel CM, Ceballos G (1995) Diversidad y conservación de los mamíferos marinos de México. Rev Mex Mastozool 1:22-43

Urbán-Ramírez J, Rojas-Bracho L, Guerrero-Ruíz M, Jaramillo-Legorreta A, Findley LT (2005) Cetacean diversity and conservation in the Gulf of California. In: Cartron JE, Ceballos G, Felger RS (eds) Biodiversity, ecosystems and conservation in northern Mexico. Oxford University Press, New York, NY, p 276-297

Wade PR, Gerrodette T (1993) Estimates of cetacean abundance and distribution in the eastern tropical Pacific. Rep Int Whaling Comm 43:477-493

Whittaker RH (1972) Evolution and measurement of species diversity. Taxon 21:213-251

Wilkinson T, Wiken E, Bezaury-Creel J, Hourigan T and others (2009) Marine ecoregions of North America. Commission for Environmental Cooperation, Montreal

- Worm B, Sandow M, Oschilies A, Lotze HK, Myers RA (2005) Global patterns of predator diversity in the open oceans. Science 309:1365-1369

Wyrtki K (1967) Circulation and water masses in the eastern equatorial Pacific Ocean. Int J Oceanol Limnol 1:117-147

Submitted: June 3, 2010; Accepted: March 7, 2011

Proofs received from author(s): May 24, 2011 